\title{
Sporobolomyces koalae sp. nov., a basidiomycetous yeast isolated from nasal smears of Queensland koalas kept in a Japanese zoological park
}

\author{
Kazuo Satoh ${ }^{1}$ and Koichi Makimura ${ }^{1,2}$
}

Correspondence

Koichi Makimura

makimura@main.teikyo-u.ac.jp

\author{
${ }^{1}$ Teikyo University Institute of Medical Mycology, 359 Otsuka, Hachioji, Tokyo 192-0395, Japan \\ ${ }^{2}$ Genome Research Center, Graduate School of Medicine and Faculty of medicine, Teikyo \\ University, 359 Otsuka, Hachioji, Tokyo 192-0395, Japan
}

\begin{abstract}
Three strains (JCM 15063 ${ }^{\top}$, JCM 15098 and JCM 15099) of a novel basidiomycetous yeast species belonging to the genus Sporobolomyces were isolated from nasal smears of Queensland koalas kept in a Japanese zoological park. Analyses of sequences of the nuclear rDNA internal transcribed spacer region and the 26S rDNA D1/D2 domain and morphological studies indicated that these strains represent a novel species with a close phylogenetic relationship to Sporobolomyces carnicolor and Sporobolomyces japonicus in the Sporidiobolus lineage, for which the name Sporobolomyces koalae sp. nov. is proposed (type strain JCM $15063^{\top}=\mathrm{CBS}$ $10914^{\top}=$ DSM $19992^{\top}$ ).
\end{abstract}

Yeast species belonging to the polyphyletic genus Sporobolomyces are anamorphic basidiomycetes that produce bilaterally symmetrical ballistoconidia and have CoQ10 or CoQ- $10\left(\mathrm{H}_{2}\right)$ as their major ubiquinone. This group is also characterized by the inability to ferment sugars, the absence of xylose in whole-cell hydrolysates and positive diazonium blue B and urease reactions (Boekhout \& Nakase, 1998). In the course of a study of the yeast microbiota of koalas, we isolated a number of basidiomycetous yeasts from Queensland koalas (Phascolarctos cinereus). In this study, we characterized three strains of basidiomycetous yeast isolated from the nasal smears of Queensland koalas kept in a Japanese zoological park (Kobe Oji Zoo, Kobe). Phenotypic, morphological and phylogenetic analyses indicated the strains to be affiliated with the genus Sporobolomyces. The data obtained also suggest that the isolates represent a novel species.

Most of the morphological, biochemical and physiological characteristics of the isolates were determined using methods described by Yarrow (1998). Nasal smears of five koalas and three zoological keepers were collected with swabs and inoculated onto CHROMagar Candida (CHROMagar) spread with micafungin (30 $\mu \mathrm{g}$ per plate).

\footnotetext{
Abbreviation: ITS, internal transcribed spacer.
}

The GenBank/EMBL/DDBJ accession numbers for the 26S rDNA D1/ D2 domain sequence and ITS sequence of strain JCM $15063^{\top}$ are EU276011 and EU276008, respectively.

A phylogenetic tree based on ITS sequences is available as supplementary material with the online version of this paper.
The nasal smears of the three zoological keepers were gathered with informed consent. Yeast DNA was extracted and purified according to the protocol recommended for the FTA Classic Card (Whatman). DNA fragments covering the nuclear internal transcribed spacer (ITS) region and the $26 \mathrm{~S}$ rDNA D1/D2 domain were amplified with primers ITS1, ITS4, 28SF1 and 635 as described previously (Mirhendi et al., 2005; Sugita et al., 2003; White et al., 1990). DNA sequencing was performed with an Applied Biosystems model 310 sequencer. The neighbour-joining tree (Saitou \& Nei, 1987) was made using MEGA3.1 (Kumar et al., 2004). Data consistency was tested by bootstrapping the alignments 1000 times with corrections for multiple substitutions. The quinone profile was determined by TechnoSuruga Laboratory Co. (Shizuoka, Japan).

Three strains (JCM $15063^{\mathrm{T}}$, JCM 15098 and JCM 15099) of red yeast were isolated from an individual koala. In phylogenetic trees drawn from D1/D2 sequences (Fig. 1) and ITS sequences (Supplementary Fig. S1, available in IJSEM Online), these strains clustered in the Johnsonii clade of the Sporidiobolus lineage (Scorzetti et al., 2002). The D1/D2 sequences showed single-base substitutions and the ITS sequences were identical. The D1/D2 domains of these koala-isolated strains showed $98 \%$ (9 substitutions, without gaps) and $97 \%$ (13 substitutions, two gaps) similarity to those of Sporobolomyces carnicolor CBS $4215^{\mathrm{T}}$ and Sporobolomyces japonicus CBS $5744^{\mathrm{T}}$. The ITS1-5.8S rDNA-ITS2 regions of the koala-isolated strains showed 93 and $91 \%$ similarity, respectively, to those of S. carnicolor CBS $4215^{\mathrm{T}}$ and S. japonicus CBS $5744^{\mathrm{T}}$. The koala-isolated 


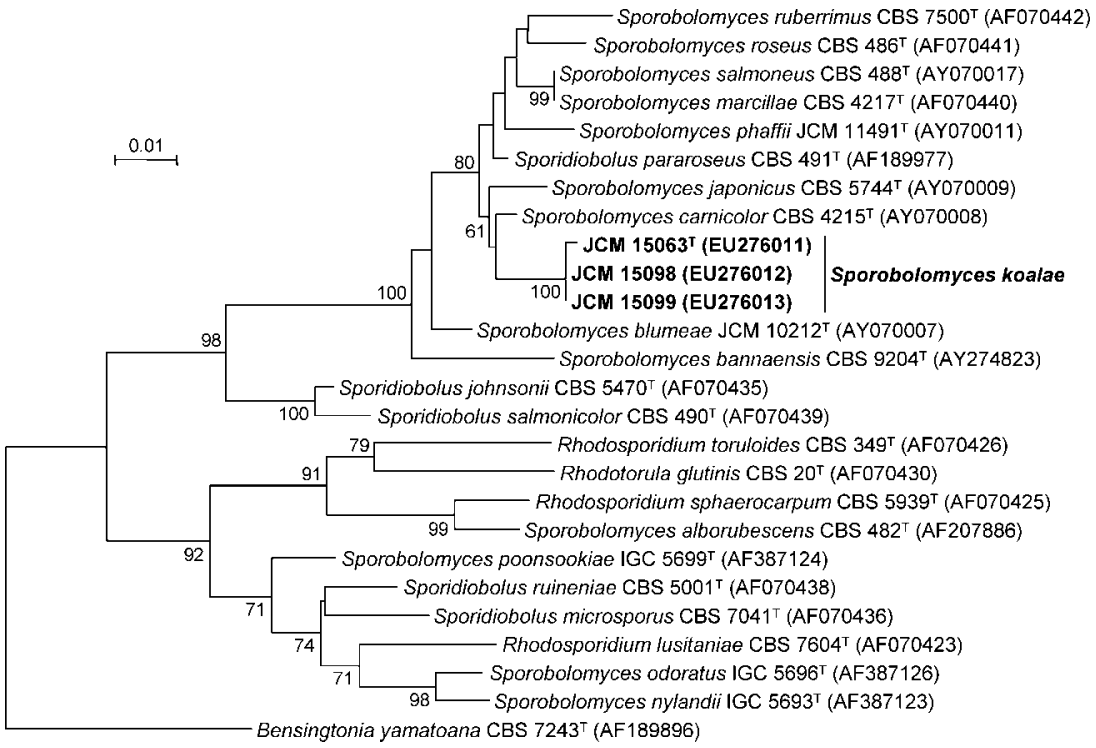

Fig. 1. Phylogenetic tree drawn from neighbour-joining analysis of $26 \mathrm{~S}$ rDNA D1/D2 domain sequences, depicting the relationships of strains of Sporobolomyces koalae sp. nov. with closely related species. Bootstrap percentages over $60 \%$ from 1000 bootstrap replicates are shown. The outgroup was Bensingtonia yamatoana CBS $7243^{\top}$. Bar, 0.01 substitutions per nucleotide position. strains were classified as belonging to the genus Sporobolomyces based on molecular systematics and culture properties.

In liquid culture (YM broth, $28{ }^{\circ} \mathrm{C}, 150$ strokes $\mathrm{min}^{-1}$ ), cells germinated with pseudohyphae (Fig. 2a). No pseudohyphae formed on cornmeal agar, malt extract agar or in broth. S. carnicolor does not form pseudohyphae (Bai et al., 2002), while S. japonicus developed pseudohyphae of the 'Candida' or 'Mycotoruloides' type (Iizuka \& Goto, 1965). The koala-isolated strains therefore differed from these species in pseudohypha formation. These results indicated that the three strains from nasal smears of Queensland koalas represent a novel Sporobolomyces species, for which the name Sporobolomyces koalae sp. nov. is proposed.
In this study, all five koalas from Kobe Oji Zoo and three zoological keepers were examined. We isolated S. koalae from three koalas, but not from any of the keepers. As cryptococcosis is a fatal disease in koala, Cryptococcus species are major targets for microbiota analysis in koalas (Makimura et al., 2002). To our knowledge, this is first report of isolation of members of the genus Sporobolomyces from koalas in Japan. Not only Cryptococcus species but also $S$. koalae were detected in nasal smears from the koalas. Members of the genus Sporobolomyces are widespread in various environments, e.g. the phyllosphere, air and also deep-sea environments (Boekhout \& Nakase, 1998; Nagahama et al., 2001). They were presumably transferred readily to nasal smears of the koala and may adapt to this environment. The pathogenicity of S. koalae
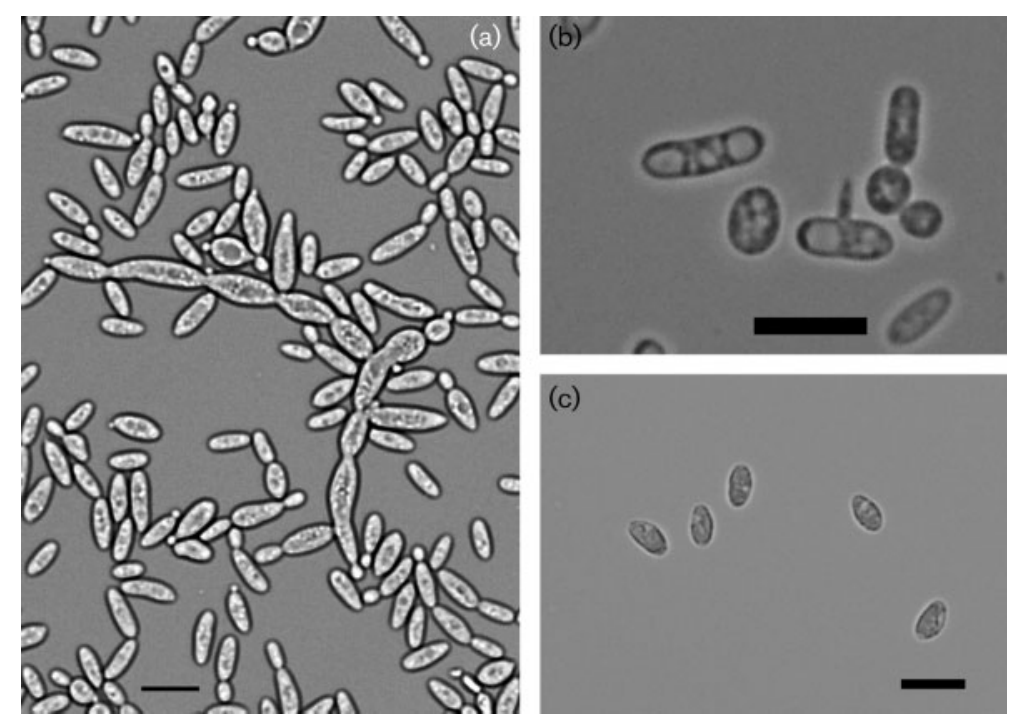

Fig. 2. Sporobolomyces koalae JCM $15063^{\top}$. (a) Vegetative cells and pseudohyphae grown in YM broth overnight at $28^{\circ} \mathrm{C}$. (b) Ballistoconidia-producing cell and vegetative cells. (c) Ballistoconidia produced on cornmeal agar after 3 days at $17^{\circ} \mathrm{C}$. Bars, $10 \mu \mathrm{m}$. 
was not determined, but it appeared to be a normal indigenous yeast, because the hosts were healthy. Further studies to determine the pathogenic presence of this yeast will be performed in future.

\section{Latin diagnosis of Sporobolomyces koalae Satoh et Makimura sp. nov.}

In liquido malti post dies 3 ad $20{ }^{\circ} \mathrm{C}$, cellulae vegetativae, ovoideae, ellipsoideae vel elongatae, 2.5-5.0 ×5.0-15.0 $\mu \mathrm{m}$, singulae, binae aut tetradium. Post unum mensem ad $20{ }^{\circ} \mathrm{C}$, annulus, pelliculum et sedimentum formantur. In agaro malti post unum mensem ad $20{ }^{\circ} \mathrm{C}$, cultura rosea, glabra, butyracea vel viscida, margine glabra. In liquido $\mathrm{YM}$ pseudomycelium formantur. In agaro farinae zeae pseudomycelium non formantur. Ballistosporae ellipsoidales vel reniformes, $\quad 2.0-5.0 \times 3.0-7.0 \mu \mathrm{m}$. Fermentatio nulla. Assimilat sic: glucosum, saccharosum, maltosum, cellobiosum, trehalosum (exigue), raffinosum, melezitosum (exigue), inulinum (exigue), amylum solubile, L-arabinosum (exigue), glycerolum (exigue), D-mannitolum, D-glucitolum (exigue), salicinum (exigue), acidum gluconicum (exigue) et acidum succinicum; non respondent D-galactosum, L-sorbosum, lactosum, melibiosum, D-xylosum, D-arabinosum, D-ribosum, L-rhamnosum, D-glucosaminum, N-acetyl-D-glucosaminum, methanolum, ethanolum, erythritolum, ribitolum, galactitolum, methyl $\alpha$-D-glucosidium, acidum DL-lacticum, acidum citricum, inositolum, hexadecanum, 2-ketogluconatum, nec xylitolum. Ammonium sulfatum et kalium nitricum assimilantur at non natrium nitrosum, L-lysinum, ethylaminum nec cadaverinum. Ad crescentiam vitaminum non necessarium est. Augmentum in $28-30{ }^{\circ} \mathrm{C}$, non-crescit in $32{ }^{\circ} \mathrm{C}$. Non respondet $50 \%(\mathrm{w} / \mathrm{w})$ GY liquido. Materia amyloidea iodophila non formantur. Urea finditur. Diazonium caeruleum B positivum. Ubiquinonum majus: Q-10. Typus stirps $\mathrm{JCM} 15063^{\mathrm{T}}$ ex nasus proluvier Phascolarctos cinereus, Japonia, isolata est. In collectionibus culturarum quas Japan Collection of Microorganisms, Wako, Saitama, sustentant, no. JCM $15063^{\mathrm{T}}$, Centraalbureau voor Schimmelcultures, Delphi Batavorum, Hollandia, sustentant, no. CBS $10914^{\mathrm{T}}$, et Deutsche Sammlung von Mikroorganismen und Zellkulturen, Braunschweig, Germania, sustentant, no. DSM $19992^{\mathrm{T}}$ deposita est.

\section{Description of Sporobolomyces koalae Satoh and Makimura sp. nov.}

Sporobolomyces koalae (ko.a'lae. N.L. fem. gen. n. koalae of a koala, Phascolarctos cinereus, from which the first strains were isolated).

After 3 days in malt extract at $20{ }^{\circ} \mathrm{C}$, cells are ovoid, ellipsoidal to elongate, $2.5-5.0 \times 5.0-15.0 \mu \mathrm{m}$, single, in pairs or groups of four. After 1 month on malt extract agar at $20{ }^{\circ} \mathrm{C}$, the streak culture is butyrous to viscous, pink to orange-red, smooth and glistening with an entire margin. Pseudohyphae are formed in YM broth on overnight cultivation at $28{ }^{\circ} \mathrm{C}$. Pseudohyphae are not formed in plate culture on malt extract agar. On cornmeal agar, ballisto- conidia are formed on short sterigmata and are asymmetrical, ellipsoidal to reniform, $2.0-5.0 \times 3.0-7.0 \mu \mathrm{m}$ (Fig. 2b, c). Fermentation of glucose is negative. The following carbon compounds are assimilated: glucose, sucrose, maltose, cellobiose, trehalose (weak), raffinose, melezitose (weak), inulin (weak), soluble starch, L-arabinose (weak), glycerine (weak), D-mannitol, D-sorbitol (weak), salicin (weak), D-gluconate (weak) and succinic acid. The following are not assimilated: D-galactose, L-sorbose, lactose, melibiose, D-xylose, D-arabinose, D-ribose, Lrhamnose, D-glucosamine, $N$-acetyl-D-glucosamine, methanol, ethanol, erythritol, adonitol, galactitol, methyl $\alpha$-Dglucoside, DL-lactic acid, citric acid, inositol, hexadecane, 2-keto-D-gluconate and xylitol. Ammonium sulphate and potassium nitrate are utilized as sole sources of nitrogen; sodium nitrite, L-lysine, ethylamine and cadaverine are not utilized. Growth in vitamin-free medium is positive. Optimum growth temperature is $28-30{ }^{\circ} \mathrm{C}$; growth is negative at $32{ }^{\circ} \mathrm{C}$. Growth does not occur in $50 \%$ (w/w) glucose/yeast extract broth. No starch-like substrate is produced. Urease activity is positive. Diazonium blue B reaction is positive. The major ubiquinone is Q-10.

The type strain, JCM $15063^{\mathrm{T}}\left(=\mathrm{CBS} 10914^{\mathrm{T}}=\mathrm{DSM}\right.$ $19992^{\mathrm{T}}$ ), was isolated from a nasal smear from a captive Queensland koala (Kobe Oji Zoo, Kobe, Japan).

\section{Acknowledgements}

We thank Dr Natsuki Hama (Kobe Oji Zoo, Japan) for sampling nasal smears. This study was supported in part by Health Science Research Grants for Research on Emerging and Re-emerging Infectious Diseases from the Ministry of Health, Labour and Welfare of Japan (K. M.).

\section{References}

Bai, F.-Y., Zhao, J.-H., Takashima, M., Jia, J.-H., Boekhout, T. \& Nakase, T. (2002). Reclassification of the Sporobolomyces roseus and the Sporidiobolus pararoseus complexes, with the description of Sporobolomyces phaffii sp. nov. Int J Syst Evol Microbiol 52, 2309-2314.

Boekhout, T. \& Nakase, T. (1998). Sporobolomyces Kluyver \& van Niel. In The Yeasts, a Taxonomic Study, 4th edn, pp. 828-843. Edited by C. P. Kurtzman \& J. W. Fell. Amsterdam: Elsevier.

lizuka, H. \& Goto, S. (1965). Microbiological studies on petroleum and natural gas. VIII. Determination of red yeasts isolated from oilbrines and related materials. J Gen Appl Microbiol 11, 331-337.

Kumar, S., Tamura, K. \& Nei, M. (2004). MEGA3: integrated software for molecular evolutionary genetics analysis and sequence alignment. Brief Bioinform 5, 150-163.

Makimura, K., Karasawa, M., Hosoi, H., Kobayashi, T., Kamijo, N., Kobayashi, K., Hiramatsu, H., Akikawa, T., Yabe, T. \& other authors (2002). A Queensland koala kept in a Japanese zoological park was carrier of an imported fungal pathogen, Filobasidiella neoformans var. bacillispora (Cryptococcus neoformans var. gattii). Jpn J Infect Dis 55, 31-32.

Mirhendi, H., Makimura, K., Zomorodian, K., Maeda, N., Ohshima, T. \& Yamaguchi, H. (2005). Differentiation of Candida albicans and Candida dubliniensis using a single PCR-restriction enzyme. Jpn J Infect Dis 58, 235-237. 
Nagahama, T., Hamamoto, M., Nakase, T., Takami, H. \& Horikoshi, K. (2001). Distribution and identification of red yeasts in deep-sea environments around the northwest Pacific Ocean. Antonie van Leeuwenhoek 80, 101-110.

Saitou, N. \& Nei, M. (1987). The neighbor-joining method: a new method for reconstructing phylogenetic trees. Mol Biol Evol 4, 406-425.

Scorzetti, G., Fell, J. W., Fonseca, A. \& Statzell-Tallman, A. (2002). Systematics of basidiomycetous yeasts: a comparison of large subunit D1/D2 and internal transcribed spacer rDNA regions. FEMS Yeast Res 2, 495-517.

Sugita, C., Makimura, K., Murai, Y., Yamaguchi, H. \& Nagai, N. (2003). A case of pulmonary aspergilloma molecular biological identification and typing of the isolates from antemortem sputa and autopsy fungus ball. Mycoses 46, 149-152.

White, T. J., Bruns, T., Lee, S. \& Taylor, J. (1990). Amplification and direct sequencing of fungal ribosomal RNA genes for phylogenetics. In PCR Protocols: a Guide to Methods and Applications, pp. 315-322. Edited by M. A. Innis, D. H. Gelfand, J. J. Sninsky \& T. J. White. New York: Academic Press.

Yarrow, D. (1998). Methods for the isolation, maintenance and identification of yeasts. In The Yeasts, a Taxonomic Study, 4th edn, pp. 77-100. Edited by C. P. Kurtzman \& J. W. Fell. Amsterdam: Elsevier. 